Article

\title{
Causes and Consequences of the Conflict among Agricultural Water Beneficiaries in Iran
}

\author{
Masoud Bijani ${ }^{1, *}\left(\mathbb{C}\right.$, Dariush Hayati ${ }^{2} \mathbb{D}$, Hossein Azadi ${ }^{3,4}\left(\mathbb{D}\right.$, Vjekoslav Tanaskovik $^{5}$ and \\ Frank Witlox $3,6,7$ (D) \\ 1 Department of Agricultural Extension and Education, College of Agriculture, Tarbiat Modares \\ University (TMU), 1497713111 Tehran, Iran \\ 2 Department of Agricultural Extension and Education, School of Agriculture, Shiraz University, \\ 7144165186 Shiraz, Iran; hayati@shirazu.ac.ir \\ 3 Department of Geography, Ghent University, 9000 Ghent, Belgium; hossein.azadi@ugent.be (H.A.); \\ frank.witlox@ugent.be (F.W.) \\ 4 Faculty of Environmental Sciences, Czech University of Life Sciences Prague, 16500 Prague, Czech Republic \\ 5 Faculty of Agricultural Sciences and Food of Ss. Cyril and Methodius University, 1000 Skopje, North \\ Macedonia; vtanaskovic@fznh.ukim.edu.mk \\ 6 Department of Geography, University of Tartu, 50090 Tartu, Estonia \\ 7 College of Civil Aviation, Nanjing University of Aeronautics and Astronautics, Nanjing 210016, China \\ * Correspondence: mbijani@modares.ac.ir; Tel.: +98-214-829-2020; Fax: +98-214-829-2200
}

Received: 20 June 2020; Accepted: 13 August 2020; Published: 17 August 2020

check for updates

\begin{abstract}
This study aimed to analyze the causes and consequences of agricultural water conflicts among agricultural water beneficiaries in the irrigation network of Doroodzan dam, Iran. This research applied mixed-method and descriptive analysis, which was done in two qualitative and quantitative phases. The results showed that the causes of water conflicts can be divided into two groups of controllable and uncontrollable factors. The findings revealed that the main causes of agricultural water conflict in the studied area were 'water scarcity', 'drought', 'physical structure of the Doroodzan dam irrigation network', and 'mismatched size of the irrigation network with Doroodzan dam's water capacity' as uncontrollable factors. Furthermore, 'weakness of governmental water management', 'lake for local management of water resources by farmers', 'government's reluctance about farmers' participation', and 'farmers' reluctance to participate in water management' were identified as controllable factors. In this study, most of the conditions identified as consequences of water conflicts had 'socio-economic' and 'agro-environmental' aspects. Finally, based on the findings, a model was designed to determine the causes and consequences of agricultural water conflict. To break the causes and consequences cycle of water conflicts in Iran's agriculture, the most important solution is shifting from governmentality to governance in water resources management.
\end{abstract}

Keywords: water conflict; governmentality; governance; Iran's agriculture

\section{Introduction}

For millennia, society has been managing disputes [1]. The political treatises of Hobbes, Locke, Rousseau, Plato, and Ibn Khaldun deal largely with the problems of conflict resolution within and among societies. The concept of conflict covers all levels in different societies and situations. All people experience conflict every day in their lives. Conflict happens when two or more people/groups have incompatible goals/actions. In this respect, "water conflict" is a term used to describe conflicts in access to water sources among exploiting societies, groups, and people. In fact, the conflict is considered an inseparable reality in life. However, we resolve the conflict in most cases. However, how is it possible 
to resolve the conflict? Certainly, awareness of the causes and consequences of conflict helps this process [2,3], and it leads to create opportunities and provide interactions among people.

The origins and frequency of conflicting behavior in each system differ depending on the form of structure and patterns of social mobility and the allocation of scarce power and property, as well as the degree to which specific power and resources are distributed [4]. Agricultural systems are no exception in this regard. In this system, there are also some elements and resources. Unequal access to resources, especially water, and the concentration of power in the hands of some stakeholders can lead to some conflicts [2].

The rapid population growth and economic progress intensified the use of energy, and water is a basic commodity for human existence [5]. Water is used for consumption, public health, industry, agriculture, and transportation. Serious water shortages can affect almost every aspect of life such as food and water security [5]. Given the importance of water, it is not surprising that it is expected to be a commodity that people are particularly concerned about its conservation and even conflict [6,7].

It is widely accepted that access to and exploitation of water resources has always been a challenging issue, causing water conflicts, struggles, and even wars inside and between societies and countries [3]. Water conflicts describe conflicts among groups, societies, or countries related to access to water [8,9]. Water disputes between two or more parties arise with competing claims about water resources and their allocation or use $[10,11]$. Here, the main question is who or what group or organization is in charge of controlling water use and plays a key role in creating, sustaining, and controlling water conflicts?

In Iran, the agricultural sector directly supports around 75\% of the population's food requirements, around $90 \%$ of the raw materials for related industries, $18 \%$ of GDP, $25 \%$ of the value of non-oil exports, and about $25 \%$ of the total jobs [12]. More than $82 \%$ of Iran's territory is located in arid and semi-arid regions, and more than $90 \%$ of the available water is used in agriculture, which leads to water shortages. Consequently, in such a case, a conflict over the use of limited water is inevitable among farmers $[7,13,14]$. Of this amount, about $50 \%$ is obtained from surface water sources and the rest from groundwater [13]. A large amount of water is wasted in the agricultural sector of Iran. The main reasons for this are mismanagement of water and rare use of advanced irrigation technologies $[15,16]$. One of the most important aspects of this phenomenon is related to water management $[17,18]$. Nowadays, a major challenge in water management is water conflict. Identification of the causes and consequences of agricultural water conflict can help manage water resources efficiently in this sector.

Iran's exploitation of its water supplies faces numerous conflicts. For example, conflicts over the Helmand River between Iran and Afghanistan exist. In addition, there are numerous other water-use conflicts within the country, such as the breakdown of the water pipeline to Yazd by East Isfahan farmers in 2012 and violent conflicts in Boldaji in 2016 over water transfers to be used in a steel factory [19]. However, many of these water contradictions are not apparent (open conflict), and many of them are hidden (latent conflict), and may suddenly erupt, like a volcano that has been quiet so far. However, no comprehensive research has been conducted to investigate the causes and consequences of water conflict in Iran's agricultural sector. In this regard, researchers have analyzed the water conflicts from different perspectives. For example, Green [20] and Bijani and Hayati $[2,19]$ have analyzed this issue from the perspective of human ecology. Malekian et al. [17] have examined it from the point of view of water security by analyzing the ontology and epistemology of the subject. Mohammadinezhad and Ahmadvand [21] have studied water conflicts in agriculture from a good governance perspective and have concluded that to reduce water conflicts, a change of water management from governmentality to governance is needed. Other studies have also looked at water conflict as a marginal view alongside other water management challenges, especially in the agriculture sector [7,12-14].

Accordingly, it seems necessary to first identify the causes of water conflicts in agriculture and secondly to examine the consequences of these conflicts in different fields (social, economic, technical, institutional, and environmental). In the next step, measures to address and manage the causes and consequences of the water conflict in agriculture should be suggested and put into practice. 
In this study, water conflict refers to focusing on local conflicts in the agriculture sector towards the use of fresh surface water, and the term 'water conflict' describes the struggles among water shareholders in the agricultural sector. The purpose of this research was to analyze the causes and consequences of water conflicts in the agricultural sector of Iran. To achieve this objective, the analysis was done using a mixed research method, by collecting the opinions of farmers (i.e., the major consumers of water in agriculture) and regional water experts (i.e., the governmental agents of water management) in the irrigation network of Doroodzan dam, located in the southwest of Iran.

The questions that this research seeks to answer are:

- What are the main causes of water conflict in the agriculture sector?

- What is the description of the types of water conflicts as perceived by respondents (farmers and water experts)?

- What are the priority and delay of water conflict causes?

- What are the consequences of water conflict in agriculture?

- How is the classification of the different causes and consequences of the water conflict?

\section{Theoretical Background}

Conflicts occur for a variety of reasons. Malthus, a leading economist, says that declining livelihoods are the main reasons for the conflict. According to him, the conflict is the result of the fact that the population is increasing in geometric progression, and the supply of food is decreasing with significant progress [20-22]. Henrik Urdal has developed models to show that countries with a high population growth rate tend not to fall into conflicts as often as the regions with a low population increase rate [23]. Therefore, one of the main reasons for water conflicts in watersheds around the world is the growth in the number of water stakeholders, which is due to urban, industrial, and agricultural development [24].

According to Green, four factors can affect the water-conflict dynamic; population, type of organization, environment, and type of technology [25]. In Iran, the direct impact of population growth on water resources management is the increasing need for drinking water in population centers (especially large cities). Indirect effects include increased demand for agricultural products, the expansion of irrigated land, the need for employment opportunities and higher incomes, and, ultimately, water conflicts, especially in agricultural sector [13]. Today, in Iran, the Water Resources Management Organization (under the supervision of the Ministry of Energy) is responsible for organizing and managing water resources. So, the government owns and controls the water. However, the government does not have an efficient mechanism for organizing water consumption in the agriculture sector $[3,19]$. Furthermore, the increasing damage of environment is one of the consequences of the growth in agricultural water conflict in Iran. Water scarcity and droughts in recent years have accelerated this process. On the other hand, agricultural water conflicts have an impact on the environment. In fact, water scarcity and unequal rights to access, use, and decide on water can be a threat to the quality of life of stakeholders and an obstacle to human and environmental development. Such conflicts can obviously influence the environment [2]. Technology interacts with population growth to bring about profound financial, organizational, and environmental improvements, all affecting natural resource rivalry [26]. Technology has an important link to conflicts over water. It can cause and reduce/regulate water conflicts [20]. In Iran's agriculture sector, one of the most important factors that have caused water conflicts is the disregard for local and indigenous technologies such as underground canals (Ghanat) as well as the incompatibility of new technologies with irrigation and water management. In Iran, after the land reform in 1962, water management has shifted to the government, the trend of water conflict has increased, and droughts of the last decade have intensified. Unfortunately, these same traditional cases have also undergone a destructive process [19].

According to Charles Darwin, the biological principles of 'struggle for existence' and 'the survival of the fittest' are the main causes of conflict [27]. In Iran, the lives of farmers depend on agriculture, 
which in turn depends on water [28]. Therefore, access to more water means a better chance of life, and this is not possible without conflict.

According to Marxist theory, power is the capacity to influence people's living conditions. Power is an important feature of society's structural relationships. The dominant power is overwhelmingly in the hands of those who own the means of production and manage it [29]. The conflict between individuals with similar desires and different resources creates social systems. In addition, individuals and resources are affected by these systems and the 'unequal distribution of power and resources in the 'society' [21,30].

Reviewing different definitions showed that "conflict" is a social situation in which two or more actors at one time want to get more access to a source or a number of sources [21,31]. In this context, the term "water conflict" is used to describe disputes between the exploiting communities, groups, and citizens in relation to water sources [9]. In water conflict divisions, there are four types, these being international, national, regional, and local conflicts, each of which can occur at four levels: No conflict, surface conflict, latent conflict, and open conflict [3]. What was considered in this study was the study of water conflict in the agricultural sector, at the regional and local levels. The water conflict, as defined by United Nations (2008) [32], is the result of conflicts between the public and private water users. In other words, water-related conflicts occur between two or more regions or groups competing with each other to access and exploit water sources [10,11].

Haftendorn (2000) [33] has listed the categories of water conflicts. For example, one state uses the river as a waterway in dispute by usage, but another state that shares the river may have environmental concerns about the effects on its territory. Practices such as constructing a dam or directing the river flow will contribute to an international conflict. Haftendorn (2000) [33] also makes reference to two types of distributional conflict: Relative and absolute shortages. The situation is very acute in the absolute shortage of water when the overall water supply is very low, such as in the semi-arid regions of the world. In relative distributional conflicts, the problem is aggravated if the lower riparian cannot prevent the upper riparian from behaving detrimentally. Agricultural water conflict is about conflicts among water stakeholders over an access to water resources in the agricultural sector [2]. In a study by Marcantonio et al. (2017) [34], they investigated the relationship between household-level attributes, water resources, and farmers' perceptions of conflict in Zambia. They developed a framework to explore this relationship as well as analyzing the impacts of farmers' perceptions of natural resources conditions (i.e., water) toward violent conflicts. They concluded that although farmers do not think water scarcity is a direct source of conflict, the understanding of decreased rain in the future is significantly related to the perception that future conflicts including violent conflict may occur. In another similar study, Zou et al. (2018) [35] attempted to understand the conflicting situation between wetland water use and agricultural water use in the Sanjiang Plain in China. Their main reason for choosing this case study was that in this area, water scarcity has become an extremely important limiting factor in wetland conservation and agricultural development, which will intensify the conflict between wetlands and agriculture for water resources. To mitigate this conflict, they suggested that adaptive wetland (e.g., precise water recharge, water transfer at stagger time, etc.) and agricultural techniques (e.g., soil water capacity increment, water saving irrigation and planting, rainfed agriculture) should be recommended to the relevant stakeholders.

According to the Homer-Dixon theory, conflicts concerning renewable natural resources have complex causes. In the 1990s, Homer-Dixon and his group carried out research on the relationship between resource scarcity and conflicts and developed their own models on the occurrence of conflicts over natural resources [36]. In the Homer-Dixon theory, environmental scarcity is triggered by three types of variables (scarcities), which are important in understanding the context of environmental conflicts: (1) Shortage of supply, (2) shortage of demand, and (3) structural shortage (Ibid). Supply-induced scarcity is when natural resources are in decline due to pollution and degradation or when the resources are limited. It could be rivers drying out due to excessive water withdrawal for agriculture or due to the lowering of groundwater tables and so on. A shortage of demand exists 
when population growth and changes in development patterns (e.g., increased welfare) contribute to higher demand, and as a result, each individual has less access to the resources. Structural scarcity is when some-often rich-actors have greater access to natural resources than the less privileged. Structural scarcity exists when it is possible for some actors to prevent other members of society from getting further access to natural resources. This type of scarcity has often been inherited from former colonial structures.

The agricultural sector is in competition with municipal and urban water users, and local water resources are under growing pressure due to increased agricultural productivity [37]. Freshwater demand in low- and middle-income countries is likely to increase with economic growth and include processes such as industrialization, energy production, health, and sanitation in arid regions, even without substantial population pressure. In a relevant study, Bohmelt et al. (2014) [38] aimed to examine how the demand for and supply of water may lead to domestic water conflict. Their findings have shown that demand-side drivers, such as population pressure, agricultural production, and economic growth, are likely to have a greater effect on water conflict than supply-side factors. In another study, Hsiang et al. (2014) [39] used macro-level meta-analysis to demonstrate a robust positive relationship between environmental change (temperature and precipitation variation) and violent conflict. O'Loughlin et al. (2014) [40] assessed the same relationship through model specification and data selection and demonstrated a result that does not include a significant relationship between precipitation and conflict. Power and wealth may still be accumulated with the help of this colonial tenure and management arrangement remnants [36]. Considering three main reasons given above, it seems that in the Iranian context, the first and third factors, namely water scarcity and structural problems in water management, are more effective in creating conflict between water stakeholders. It has been also acknowledged by previous researches [2,3].

The interaction of environmental scarcities in various patterns tends to change societies in developing countries. These changes, in turn, may increase the risk of environmental conflict and stress. Homer-Dixon has recognized five social effects related to resource scarcity: (1) Limited agricultural productivity, often in peripheral areas in terms of the environment; (2) limited economic productivity, mainly affecting people who are highly dependent on natural resources and are environmentally and economically marginalized; (3) the division of society, usually along existing ethnic divisions; (4) the disruption of institutions, especially the state; and finally, (5) the reduction in the number of affected people in search of better lives [36]. The social effects mentioned above can act individually or combined with each other and result in further stress on society [36].

Although there are many theoretical discussions about conflicts and their reasons and consequences, this discussion has not been much considered about water use and management, especially in the agricultural sector of Iran. Undoubtedly, identifying these reasons and consequences as the main goal of this research focusing on the agricultural sector of Iran is the novelty of this study and it can be a turning point in improving water resources management.

Uncertainties about water conflict in agricultural sector has many aspects. One of the most important aspects and maybe the most important one in this regard is "management". Management can present and introduce environmental and conservation values to make efficient changes into water beneficiaries' beliefs and norms. The previous studies did not focus on the balance of power towards water management. To fill this gap, using mix-method approach (qualitative and quantitative), this study attempts to answer the following questions: 'does the type of water management cause water conflict?' and 'which type of management can lead to less water conflict?'

\section{Materials and Methods}

\subsection{Research Design}

It was an applied study in terms of study orientation using a mixed-method sampling to assess the nature of the problem. It was also a non-experimental research in terms of the level and degree of 
variables regulation, and descriptive and ex-post facto in terms of the test type. More importantly, the research has been performed using two surveys (Figure 1).

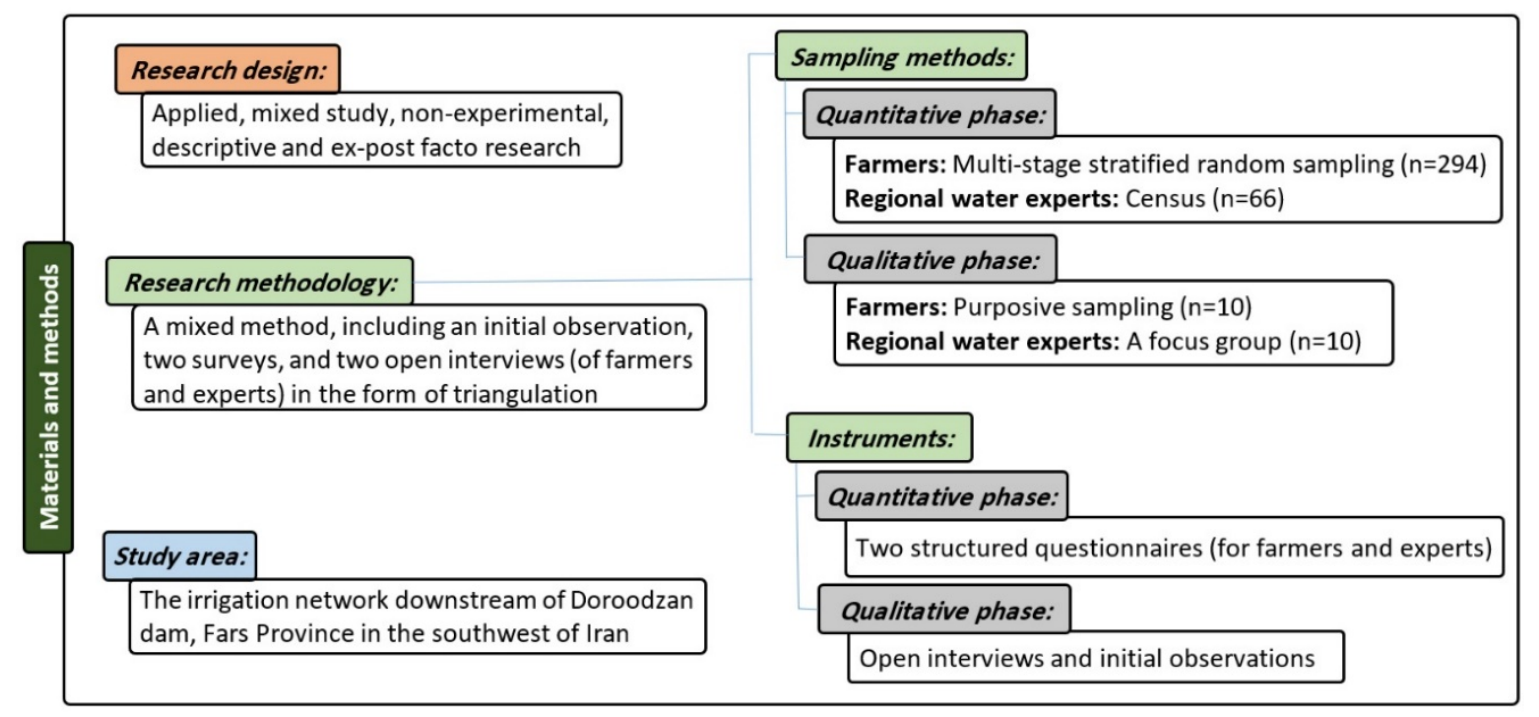

Figure 1. The flow chart of research methodology steps. Source: Study finding.

\subsection{Study Area}

The study was conducted in the irrigation network downstream of Doroodzan dam, Fars Province in the southwest of Iran (Figure 2). Fars is one of the largest provinces $\left(121,000 \mathrm{~km}^{2}\right.$; about $7.5 \%$ of Iran's territory) and the largest population (more than 4 million people) in the country. Fars province is one of the leading regions producing of agricultural products (wheat-producing province), although it has recently faced drought [41]. Doroodzan dam —one of the largest reservoirs in Fars province-provides water for $4200 \mathrm{~km}^{2}$ of agricultural land. It is also one of the main suppliers of drinking water to the cities of Shiraz and Marvdasht [42]. The irrigation network of Doroodzan dam consists of eight sections/canals: Main, Ordibehesht, Hamoon, left, Amir, Faizabad, Tilakan, and Mavan. Doroodzan dam was constructed in 1971 to provide irrigation water for the farms and to supply drinking water for Shiraz. The dam average depth is $30 \mathrm{~m}$ and it is equipped with 29 hydraulic pyrometers and 14 standpipe pyrometers. The reservoir volume is 993 million cubic meters at the normal pool level and the dam crest length is $\sim 700 \mathrm{~m}$.

The construction and development of irrigation and drainage networks in downstream areas of the dam is a very important infrastructural plan and its implementation could improve the efficiency of water use in agricultural activities, especially in terms of water conflict. The Regional Water Organization has tried to develop irrigation and drainage networks with regard to current drought, water scarcity, and low surface water use efficiency in the Doroodzan dam downstream in Fars province. In this regard, the agricultural water beneficiaries who have more social participation, more contribution in local decision-making, and more crop under cultivation would have significant roles in supporting the canals construction of Doroodzan dam [43].

Doroodzan irrigation and drainage network is divided in 6 construction units. Water conveyer canal of unit 1, with concrete lining, is called "Main canal" and is about $22.2 \mathrm{~km}$ long. The canal has a lateral called Abraj and 5 tertiary canals named T4, T5, T6, T8, and T14. Main canal contains 16 offtake structures and covers the command area of about 11,350 ha. Considering the total capacity of the canal and feeding six construction units (with the overall area about 51,000 ha), the capacity of the canal does not seem enough. Therefore, ground water as the second accessible water source plays an important role in supplying the irrigation water of some units of Doroodzan network. Main canal, as Doroodzan water conveyor of irrigation and drainage network, starts at powerhouse outlet of reservoir 
dam and ends up in water distributor structure, after covering a distance of $22.2 \mathrm{~km}$ from northwest to southwest.

The volume of water stored in the Sivand dam $\left(255\right.$ million $\left.\mathrm{m}^{3}\right)$ is approximately one-third of the Doroodzan dam $\left(770\right.$ million $\left.\mathrm{m}^{3}\right)$. In addition, most of the water from these two dams is used for urban consumptions and is available to farmers only for a limited period of time. Particularly, the Sivand river flows in downstream areas with low water only a few months of the year. Most of the water allocated to the agriculture sector is also consumed in upstream areas of the Sivand river before reaching the Doroodzan dam irrigation network.

As shown in Figure 2, the waterlogged in upstream areas of the Sivand river are outside the Doroodzan dam irrigation network (the area of Doroodzan dam irrigation network is shown in dark blue). The bottom part of the Sivand river (with limited water) is located at the border between downstream and upstream of the dam irrigation network, so that the downstream and the upstream areas equally benefit from the river. In addition, in the Doroodzan dam irrigation network, the canals are branched off from the Kor river and the farmers benefit from them, but no such canals are provided for the Sivand river. Therefore, the presence of the bottom part of the Sivand river in the Doroodzan dam irrigation network does not make a significant difference in the amount of water available to farmers in the upstream and downstream areas of this network. In this way, its minor effect on both upstream and downstream areas is considered to be the same.

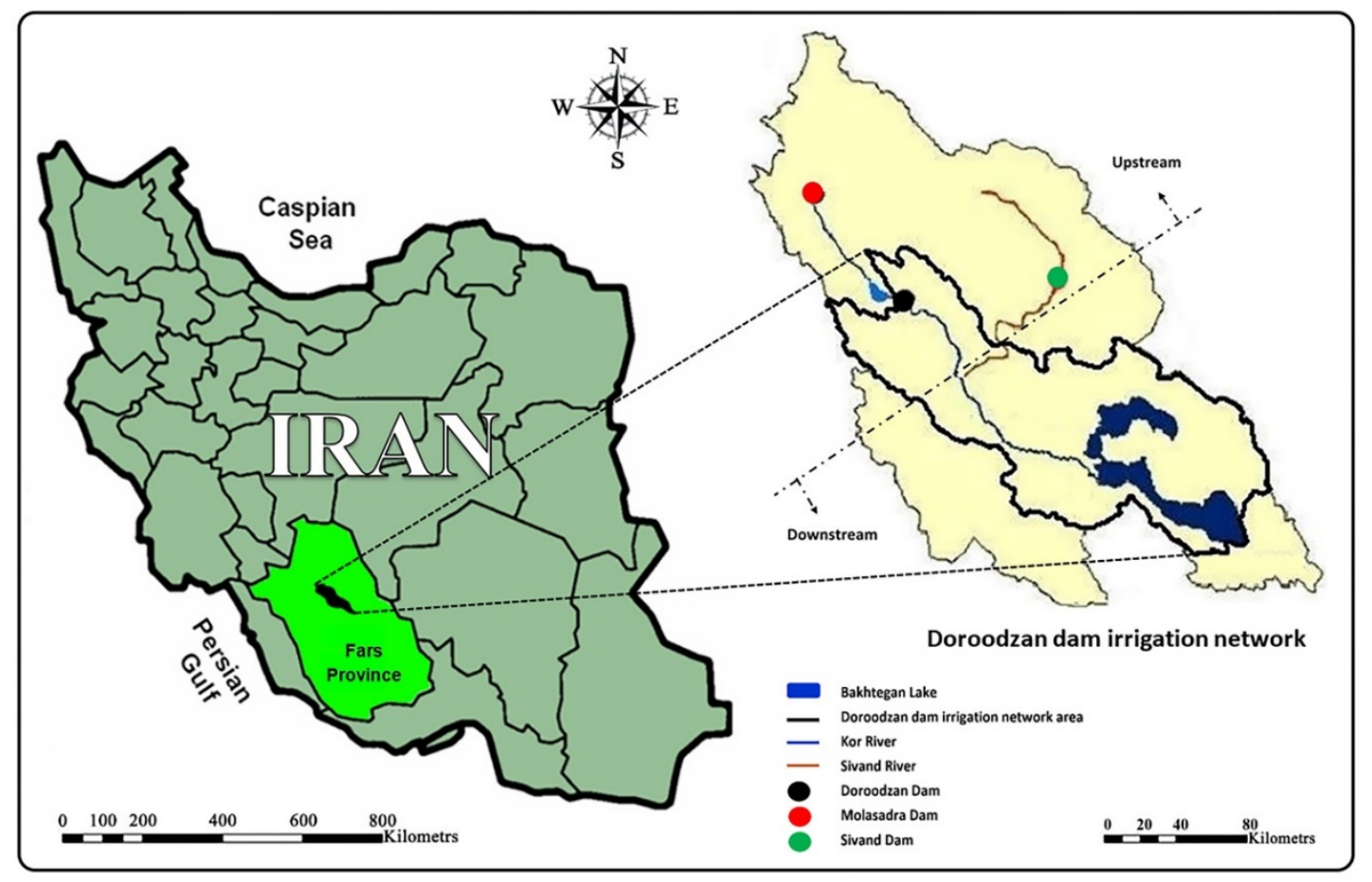

Figure 2. The study area in Fars province, Iran.

\subsection{Research Methodology}

This applied study was conducted with a mixed method, including an initial observation, two surveys, and two open interviews (of farmers and experts) in the form of triangulation. These methods were conducted after initial observations and in-depth study. In other words, quantitative and qualitative methods were used to investigate similar research questions.

Respondents of this study included farmers and regional water experts. Furthermore, since there are two research methods (qualitative and quantitative), two samples were selected from each group. 


\subsubsection{Sampling Methods}

Farmers

In the quantitative phase, multi-stage stratified random sampling has been used to select a sample of farmers $(n=294)$. From each area (eight areas mentioned above), five villages were randomly selected (as stage 1, random sampling), resulting in a total of 40 villages. Then, seven or eight farmers were randomly selected from each village according to its population (as stage 2 , stratified random sampling method). Moreover, using purposive sampling, 10 farmers (five people in upstream and five in downstream) were interviewed in the qualitative phase.

\section{Regional Water Experts}

The number of regional water experts who worked (as governmental or government-related agents) in Doroodzan dam irrigation network was 75. All of the experts were approached and, finally, 66 questionnaires were completed. In the qualitative phase, a focus group was formed with 10 experienced experts.

\subsubsection{Instruments}

\section{Quantitative Phase}

Data were collected using two structured questionnaires (for farmers and experts). Their 'face validity' was confirmed by a panel of experts in agricultural extension and water resources management. In addition, the reliability of questionnaires was obtained through a pilot study using Cronbach's alpha coefficient (Table 1). The data obtained through the questionnaires were analyzed using SPSS24.

Qualitative Phase

Data were collected using open interviews and initial observations. The data obtained through interviews were evaluated using the enumeration technique.

Table 1. Reliability outputs.

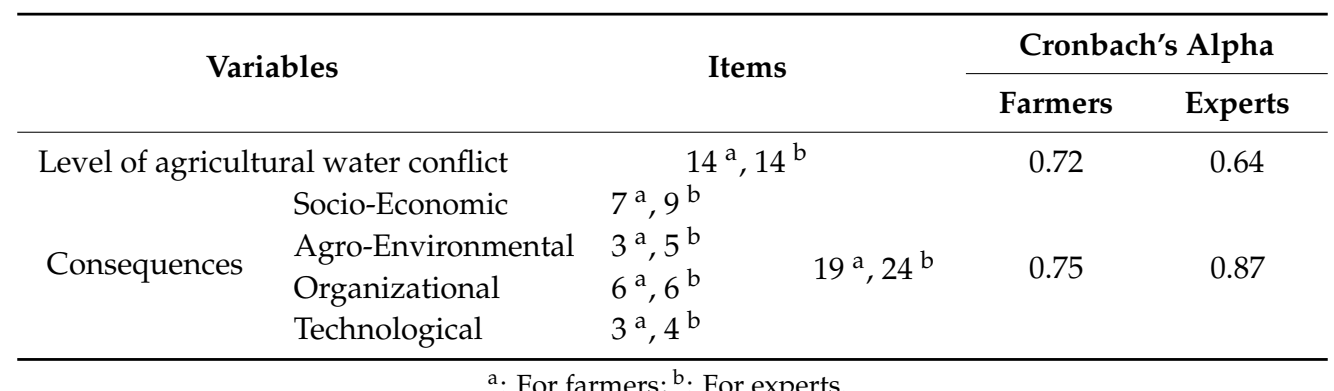

\section{Results}

\subsection{The Level of Agricultural Water Conflict}

In this study, agricultural water conflict was measured through 14 items in the quantitative phase via two surveys (Table 2 and Figure 3). Frequency results for the farmer population revealed that in a range from 0 to 5 (zero meaning no water conflict and 5 meaning very high-water conflict), farmers have reported moderate to high levels of water conflicts. In this regard, a range from 1 to 10 was considered for experts. Findings for experts were more or less similar to that for farmers. Thus, the total agricultural water conflict ranged from 0 to 70 for farmers and 14 to 140 for experts. Most farmers 
(over 85\%) and specialists (over 90\%) rated agricultural water conflicts between moderate and high (Figure 3). These findings show that agricultural water conflict in this area is quite serious.

Table 2. Agricultural water conflict levels: Surveys' results.

\begin{tabular}{ccccccc}
\hline \multirow{2}{*}{$\begin{array}{c}\text { Level of Water } \\
\text { Conflict }\end{array}$} & Frequency & Percent & $\begin{array}{c}\text { Cumulative } \\
\text { Percent }\end{array}$ & Frequency & Percent & $\begin{array}{c}\text { Cumulative } \\
\text { Percent }\end{array}$ \\
\cline { 2 - 6 } & 0 & 0 & 0 & 0 & 0 & 0 \\
No conflict & 3 & 1 & 1 & 0 & 0 & 0 \\
Very low & 23 & 7.8 & 8.8 & 2 & 3 & 3 \\
Low & 126 & 42.9 & 51.7 & 34 & 51.5 & 54.5 \\
Moderate & 129 & 43.9 & 95.6 & 27 & 40.9 & 95.4 \\
High & 13 & 4.4 & 100 & 3 & 4.6 & 100.0 \\
Very high & 294 & 100 & & 66 & 100 & \\
\hline Total & & & & & Fxperts $^{\mathbf{b}}$ \\
\hline
\end{tabular}

a: Responses weighted 0 to 5: from none (0), very low (1), low (2), moderate (3), high (4) and very high (5).

$\mathrm{b}$ : Responses weighted 1 to 10: from very low (1) to very high (10).

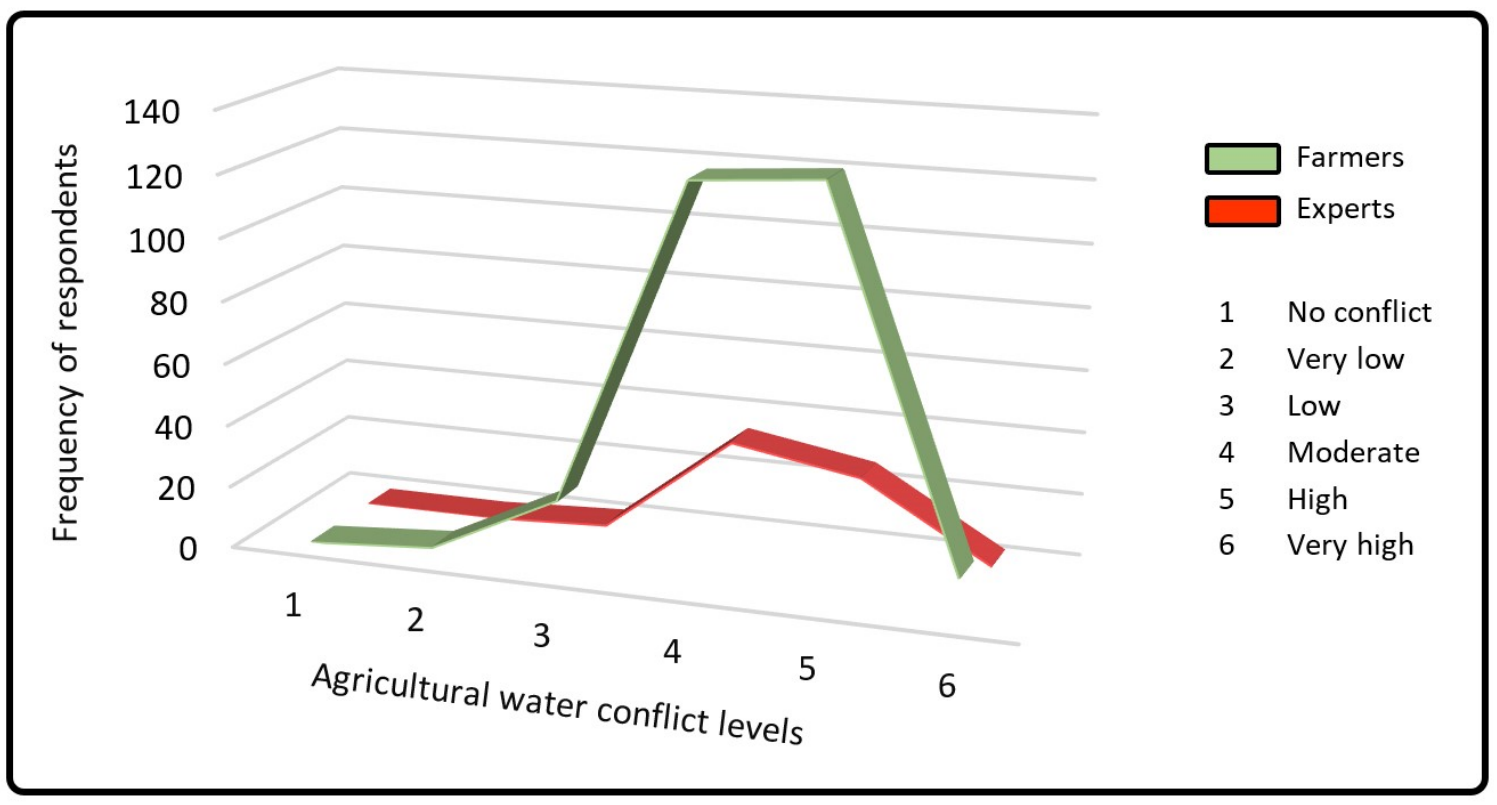

Figure 3. Agricultural water conflict levels according to respondents' opinion. Source: Surveys' results.

\subsection{Causes of Agricultural Water Conflict}

\subsubsection{Causes: Observations and Archival Search Results}

Primary observations and archival search identified that the causes of water conflicts in the agricultural sector are as follows:

- Differences in the government's goals (as the director of water resources) and farmers' goals (as users of water): Today, in Iran, the Water Resources Management Organization (under the supervision of the Ministry of Energy) is responsible for organizing and managing water resources. So, the government owns and controls the water. In fact, the water management type in Iran is governmental. In this regard, the government's goal is water distribution among water stakeholders (municipality, industry, agriculture, and environment consumptions). However, the available water is low, and the government does not have the ability to distribute it justly. Moreover, the government has an important responsibility towards some other priorities such 
as water sustainability and pollution. On the other hand, the farmers' goal is to increase their agricultural production and income; for this purpose, they need more water.

- Water distribution method by the government (water distribution policy): In the Doroodzan dam irrigation network, there is a contract between the government and farmers with regard to water allocation based on the land size (i.e., hectares). Therefore, the water supply cost that every farmer pays to the government is based on his/her land size. It should be mentioned that the type and volume of cultivation are different from farm to farm. Furthermore, their distance from the dam is different; therefore, upstream farmers who are near the dam can access more water.

In this regard, to develop equity in water distribution, the best way is to change the price basis from land size to water use volume measurement. This means that the water distribution contract should be based on the volume of water used per year by each farmer. In this case, it would be known exactly how much water each farmer would receive, and water will be allocated based on the amount of water stored in Doroodzan dam; all farmers will be equitably benefited from the water distribution. Creation and expansion of the water distribution network through major and minor irrigation canals and the use of intelligent surveillance systems are appropriate solutions for developing equity in water distribution as a volume format among farmers.

- The government's reluctance about farmers' participation in water management: The government has no interest in enabling the participation (as an active and self-mobilizations participation) of stakeholders in water resource management. In fact, it is generally the case that water management is in the monopoly and control of the government. Due to this trend, the conflict between the government and farmers will increase and farmers will not have any trust in the water management.

- Farmers' reluctance to participate and cooperate in water resource management: Descriptive statistics showed that $48.3 \%$ of farmers prefer that the government retains charge of the management of agricultural water resources; $26.2 \%$ believe they should manage water affairs themselves, and $25.5 \%$ prefer a combination managing by both of them (the government and farmers). In fact, farmers avoid managing water resources by themselves and prefer the management to be executed by the government. Lack of unity among farmers and lack of local associations for water management and distribution may be some reasons for such findings. This factor, along with the previous factor (the government's reluctance about farmers' participation in water management), is a serious obstacle for farmers' participation and their cooperation with the government.

- The physical structure of Doroodzan dam irrigation network: Most canals downstream of the Doroodzan dam are old and worn out. Therefore, water flow and distribution are difficult. Time taken for water transferring is high; therefore, a lot of water is lost because of low irrigation efficiency by the old canals. This is because the bottom of the canals is broken in many parts, causing water to leak. Barriers have been created in the canals that affect the volume and timing of water flow. Furthermore, in the upstream, the network has been used for more than 30 years and necessary reconstructions have not been done; therefore, according to the technical view, the irrigation network is considered to be old. This is why irrigation efficiency is low.

- Mismatch of current water beneficiaries' demand with Doroodzan dam water capacity: The Doroodzan dam was designed to irrigate about 40,000 hectares. After the political revolution and because of the lack of control by the government, development farming and land cultivation have increased to around 80,000 hectares (twice the capacity of the dam); this has increased pressure on Doroodzan dam. Moreover, the need for drinking water in two big cities (Shiraz and Marvdasht) that are expanding constantly, some large industrial enterprises near the dam, and industrial water usage in the petrochemical industry are all taken care of by the Doroodzan dam. The mismatch between the capacity of the dam and water requirement is increasing. This is one of the most important reasons for the growing agricultural water conflict. 


\subsubsection{Causes: Surveys Results}

For a deeper understanding of the causes of water conflict in the agricultural sector, two surveys were conducted among farmers and experts. The results showed that in addition to the factors mentioned earlier, certain other factors (Figure 4) could be the cause of agricultural water conflicts. Figure 4 identifies and highlights some elements that can be the cause of agricultural water conflict among water stakeholders. According to this figure, in terms of their importance in the field of water conflict in the agriculture sector, the variables have been ranked, respectively. According to the farmer's opinion, 'water scarcity' was at the first rank and 'drought' held the second rank. On the other hand, experts believed that 'drought' was the most important cause of agricultural water conflict, and 'water scarcity' was in the next rank. In fact, in recent years, the conflict among stakeholders has increased due to the unauthorized use of surface and groundwater resources in the agriculture sector. Water scarcity and drought have a close relationship with each other, which explains their top ranking. According to Yazar et al. (2009) [44], water scarcity and drought are the major factors constraining agricultural crop production in arid and semi-arid zones of the world. Water scarcity is long term and its driving forces are as follows: Natural (low precipitation), human-driven (overexploitation, pollution). In turn, drought is a temporary decrease of water availability and its driving force is natural, related to seasons [45].

The third and fourth most important points from farmers and experts' opinions are associated with water management. One of the problems in many villages in the study area was the impossibility of drilling wells. The sixth rank is related to this case for farmers. However, experts set it on the last rank. Based on the observations in several downstream villages (such as some villages in Amir segment), it is not possible to dig wells even for drinking water because the groundwater in the area is saline. According to the respondents' viewpoints (farmers and experts), the role of population growth (population of water stakeholders) had the lowest effect on water conflict (11th rank in Figure 4). This finding is contrary to the theory of Malthus, which argued that conflict is caused by the increase in population. It is also contrary to Green's research [19]. However, it confirms the finding of Urdal's study $[2,18,20,22]$, as was mentioned earlier. Other priorities and comparison between them can be seen in Figure 4.

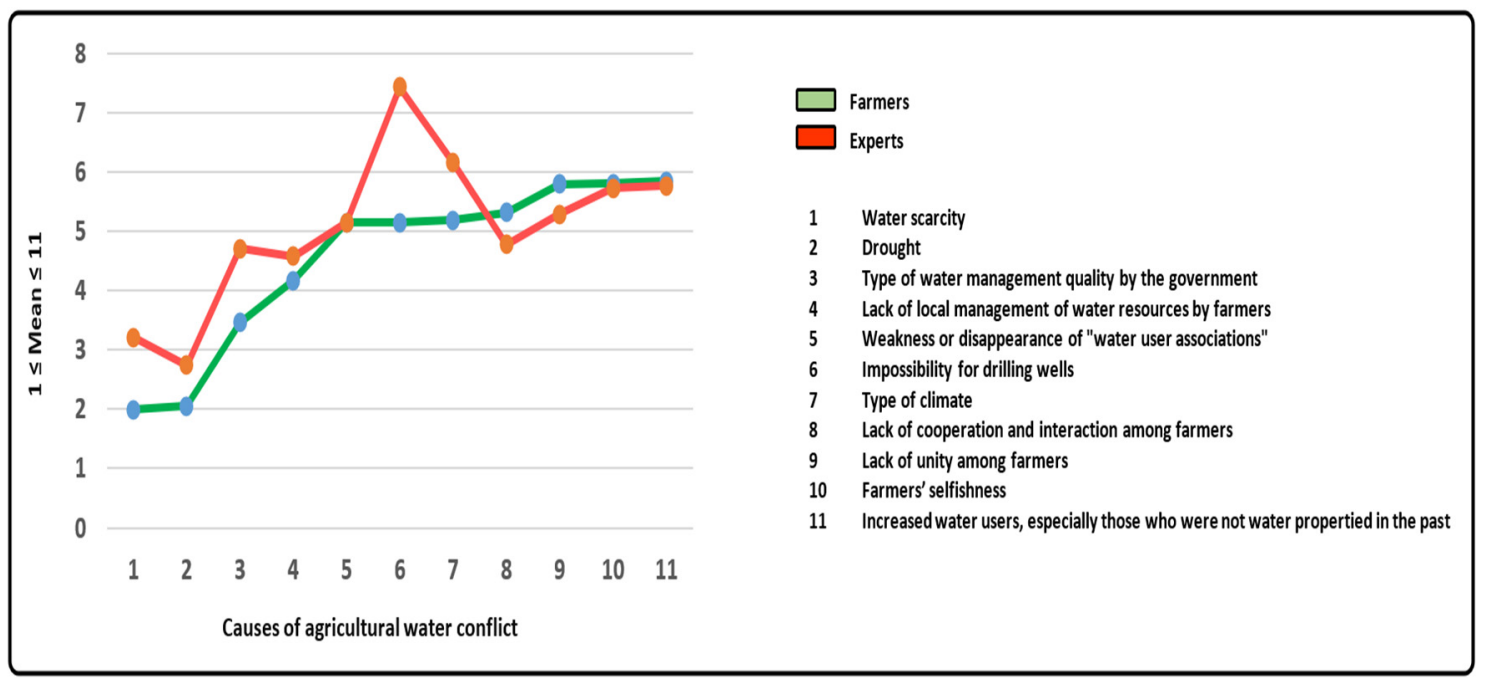

Figure 4. Causes of agricultural water conflict according to respondents' opinion. Source: surveys result.

\subsubsection{Causes: Interviews Results}

To fully understand the causes of agricultural water conflicts, an open interview was conducted among 10 farmers, who were selected in the qualitative phase of research. Repeated concepts in their statements about the causes of water conflicts were recorded. Separation and enumeration of these 
concepts are presented in Table 3. The concepts were classified into eight categories. They are 'climatic', 'management', 'economic', 'social', 'technical', 'human', 'political', and 'metaphysical' factors. The total score of repetitions showed that climatic, management, and economic factors had a major role in water conflicts. In this regard, scarcity, drought, low rainfall, proximity to major cities (Shiraz and Marvdasht), poor water management by the government, decrease in production and income, increasing agricultural costs, and impossibility of drilling wells were the most frequent reasons mentioned by the farmers.

Table 3. Analysis of water conflict causes by enumeration technique.

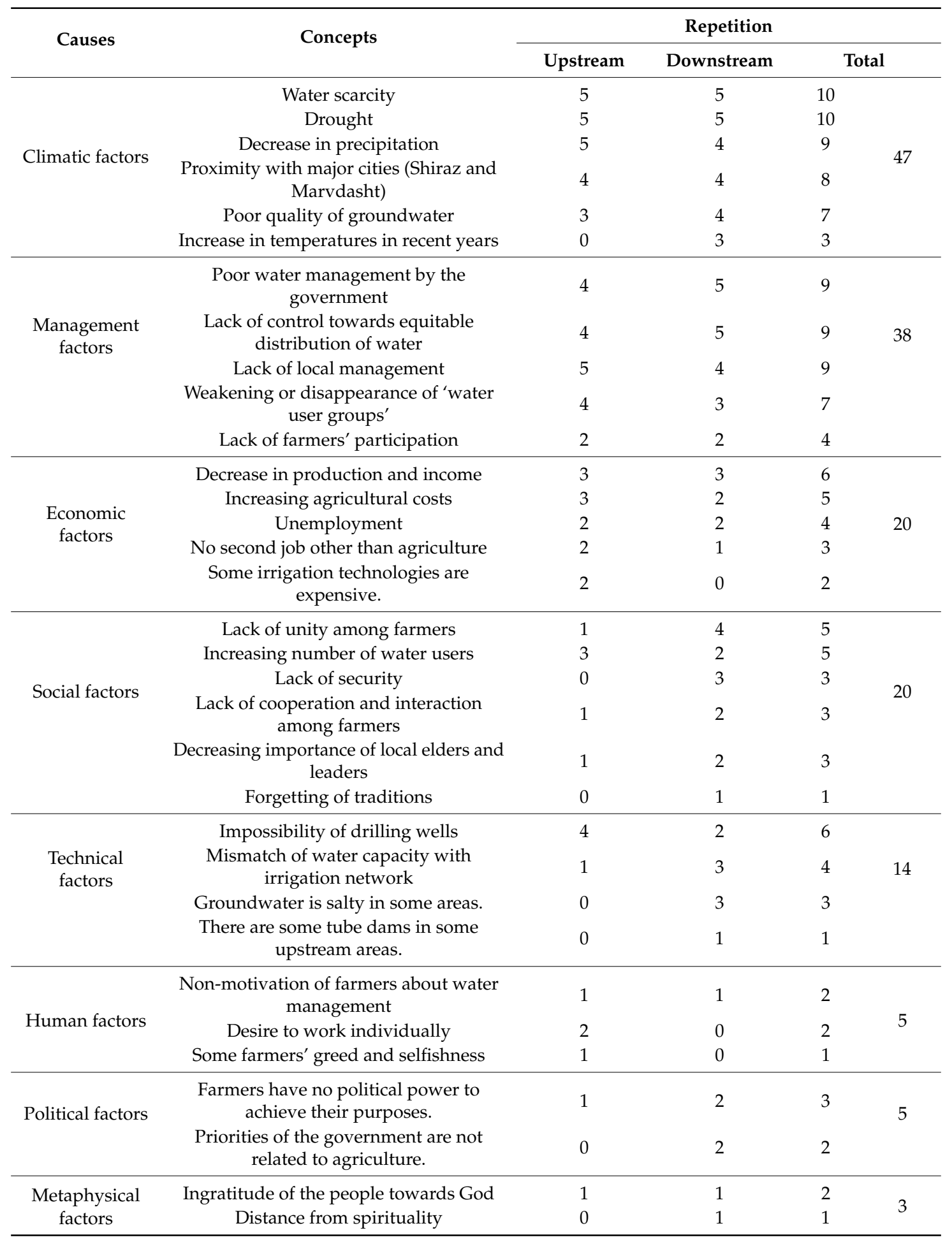




\subsection{Consequences of Agricultural Water Conflict}

\subsubsection{Consequences: Observations and Archival Search Results}

Primary observations and archival search have identified the causes of water conflicts in the agricultural sector as follows:

- Abandoning agriculture and pursuing other career options: Agriculture depends on water. However, water is limited. Unequal access to water and the resulting incidence of conflict towards using water reduce the income of farmers. In such cases, searching for other jobs to earn more income is inevitable. In the study area-particularly downstream of the Doroodzan dam-it was observed that about $40 \%$ of the farmers have a second job. Often, these second jobs are not high level and do not need much expertise. Some of these jobs somehow cause damage to the environment. For example, some farmers have created a source of income for themselves by catching and selling some rare animal species or by poaching.

- Migration: Due to the chain of water scarcity, conflict, and loss of income, some rural farmers are not able to remain in the villages and migrate to urban areas (especially to Shiraz and Marvdasht) for other permanent or seasonal jobs. This confirms Said's findings. Said has identified different types of concerns that trigger environmental conflicts, which Said calls them 'demographically caused migration conflicts'. This happens when there is an increase in population pressure in environmentally weak regions. Another type of conflict is 'ethno-political conflicts', when two or more ethnic groups have to share the same natural recourse [34].

According to Homer-Dixon's theory, resource capture happens when a resource decreases due to population increase. When the resource declines, the strong actors in the society may capture the resources; they may use their power and their self-interest to influence the institutions responsible for the resources to gain increased access. As a result, poorer groups in society become even more marginalized (from the ecological perspective) due to the unfair allocation of resources. These people are forced to migrate to and cultivate areas that are ecologically fragile. Therefore, additional resource degradation takes place [34].

- Reduction of young labor in the agriculture sector: Reduced motivation to work in the agricultural sector is partly due to water conflicts. Conflict studies show that with regard to the use of natural resources, conflicts among elders are rarer than those among younger people. However, other sources of income outside agriculture are more attractive to young people. Abandoning agricultural and rural areas through young people might be at the cost of agricultural sector decay. One of the most important consequences of water conflict is "social", which has many consequences. One of the reasons for this is the weakness in the agricultural profession and the consequent departure of some farmers (especially young farmers) from the agricultural sector. This will lead to their involvement in other professions, especially in the urban services sector and their migration from rural areas.

- Damage to irrigation canals (water theft): A common practice, particularly in upstream areas of the Doroodzan dam, is to damage some parts of irrigation canals and valves to get more water by the same farmers. Furthermore, in some regions, farmers extract water from canals illegally by using motor pumps. In this way, less water will be available in downstream areas. Sometimes, water conflicts become so intense that military forces have to enter the field.

- Failure to cooperate with the government for irrigation projects: Conflict among farmers and between farmers and the government sometimes prevents the rapid execution of irrigation projects by the government. For example, many farmers, to get more water, do not allow crossing of canals in some areas. Sometimes, they do not allow crossing of canals from their land because parts of their lands are occupied by canals and they prefer these traditional canals. Sometimes, farmers of villages that are closer to the irrigation canals get into a dispute with other villages. 


\subsubsection{Consequences: Surveys Results}

Consequences of water conflict were placed in four categories: 'socio-economic', 'organizational', 'agro-environmental', and 'technological' consequences. These factors have been investigated in the quantitative phase. In this regard, some items were considered for each factor (Table 4).

Table 4. Consequences of agricultural water conflict: Focus group results.

\begin{tabular}{|c|c|c|}
\hline & Consequences & Index \\
\hline \multirow{9}{*}{$\begin{array}{l}\text { Socio-economic } \\
\text { consequences }\end{array}$} & Water conflict causes decrease in income of rural people. & SE1 \\
\hline & Water conflict causes increase in costs for farmers. & SE2 \\
\hline & $\begin{array}{l}\text { Water conflict causes migration some farmers from rural areas } \\
\text { and decrease in rural population. }\end{array}$ & SE3 \\
\hline & $\begin{array}{l}\text { Water conflict causes increase in governmental costs towards } \\
\text { water management. }\end{array}$ & SE4 \\
\hline & Water conflict causes other social problems and frictions. & SE5 \\
\hline & $\begin{array}{l}\text { With increasing water conflict, economic collaborations decrease } \\
\text { among farmers from other backgrounds. }\end{array}$ & SE6 \\
\hline & $\begin{array}{l}\text { Water conflict causes increase in lack of security in the } \\
\text { Doroodzan irrigation zone. }\end{array}$ & SE7 \\
\hline & $\begin{array}{l}\text { Water conflict creates safe competitions (in agricultural view) } \\
\text { among farmers. }\end{array}$ & SE8 \\
\hline & $\begin{array}{l}\text { Water conflict is a natural and common phenomenon that has } \\
\text { always existed and will always exist. }\end{array}$ & SE9 \\
\hline \multirow{5}{*}{$\begin{array}{l}\text { Organizational } \\
\text { consequences }\end{array}$} & $\begin{array}{l}\text { With growing conflicts over the use of water, collaboration } \\
\text { among farmers has declined in the form of water-user groups. }\end{array}$ & O1 \\
\hline & $\begin{array}{l}\text { Water conflict is an obstacle for the government's attempts to } \\
\text { organize farmers. }\end{array}$ & $\mathrm{O} 2$ \\
\hline & $\begin{array}{l}\text { Water struggles lead to stratification of farmers against each } \\
\text { other. }\end{array}$ & $\mathrm{O} 3$ \\
\hline & $\begin{array}{l}\text { Water conflict causes decline in farmers' participation in water } \\
\text { management. }\end{array}$ & $\mathrm{O} 4$ \\
\hline & $\begin{array}{l}\text { Water conflict has no special consequences towards social or } \\
\text { administrative organization of farmers. }\end{array}$ & O5 \\
\hline \multirow{6}{*}{$\begin{array}{l}\text { Agro-environmental } \\
\text { consequences }\end{array}$} & With water conflict, planting of some crops is impossible. & AE1 \\
\hline & $\begin{array}{l}\text { With growing water conflict, many farmers are forced to reduce } \\
\text { their level of farming. }\end{array}$ & AE2 \\
\hline & $\begin{array}{l}\text { Water conflicts cause increase in inappropriate exploitation of } \\
\text { the environment. }\end{array}$ & AE3 \\
\hline & $\begin{array}{l}\text { With growing water conflict, flora and fauna have been } \\
\text { compromised in Doroodzan irrigation zone. }\end{array}$ & AE4 \\
\hline & $\begin{array}{l}\text { With growing water conflict, participation and collaboration of } \\
\text { farmers towards protection of environment have declined. }\end{array}$ & AE5 \\
\hline & $\begin{array}{l}\text { With growing water conflict, farmers' greed towards the use of } \\
\text { water has increased. }\end{array}$ & AE6 \\
\hline \multirow{4}{*}{$\begin{array}{l}\text { Technological } \\
\text { consequences }\end{array}$} & $\begin{array}{l}\text { Water conflicts lead to the resistance of farmers against irrigation } \\
\text { projects of water organization. }\end{array}$ & $\mathrm{T} 1$ \\
\hline & Water conflicts cause farmers to reject irrigation technologies. & $\mathrm{T} 2$ \\
\hline & $\begin{array}{l}\text { Water conflicts lead farmers to use advanced technologies to } \\
\text { acquire more water. }\end{array}$ & T3 \\
\hline & $\begin{array}{l}\text { Water conflicts cause increase in adoption of new technologies } \\
\text { towards use of water. }\end{array}$ & $\mathrm{T} 4$ \\
\hline
\end{tabular}

Descriptive statistics pertaining to each item regarding the opinion of respondents towards water conflict consequences are presented in Table 5. The findings in this table reveal that farmers and experts have the same opinion about socio-economic and agro-environmental consequences. They placed 
these outcomes in moderate to high range. The second priority relates to organizational consequences, which experts evaluated in moderate to high range and farmers estimated as moderate. The last priority relates to technological consequences, which were estimated in a moderate range by experts and low to moderate range by farmers (Figure 5). The findings in Table 5 show that the impact of water conflict on income and agricultural costs for framers had priority regarding socio-economic consequences. In this regard, increasing governmental costs towards water management is the last priority for them. For experts, other social problems due to water conflict were ranked first, and creation of safe competitions was ranked last.

With regard to organizational consequences, from the farmers' viewpoints, the first rank was given to the organization of farmers by the government. In fact, they believed that with increasing water conflicts, the government cannot successfully organize farmers to use water. The experts had the same idea in this respect.

With regard to agro-environmental consequences for farmers, reducing the level of farming was in the first rank, while for experts, the first rank was about the increase in farmers' greed towards the use of water.

The first rank for both farmers and experts about technological consequences was about the point that water conflicts lead to resistance of farmers against irrigation projects of the water organization. Other priorities can be seen in Table 5.

Table 5. Consequences of agricultural water conflict: Surveys' results.

\begin{tabular}{|c|c|c|c|c|c|c|c|c|c|c|c|c|c|}
\hline \multirow[b]{2}{*}{ Consequences } & \multicolumn{7}{|c|}{ Farmers $^{a}$} & \multicolumn{6}{|c|}{ Experts $b$} \\
\hline & 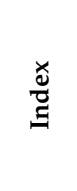 & $\sum_{\Sigma}^{\Xi}$ & 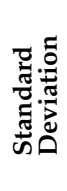 & 胥 & 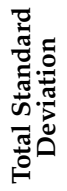 & $\begin{array}{l}\stackrel{\mathscr{\infty}}{\leftrightarrows} \\
\stackrel{\Xi}{\approx}\end{array}$ & $\sum_{\tilde{J}}^{\infty}$ & $\stackrel{\Xi}{\Sigma}$ & 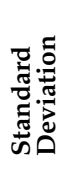 & 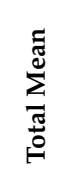 & 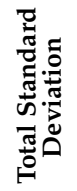 & 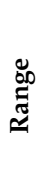 & 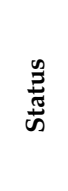 \\
\hline \multirow{9}{*}{$\begin{array}{l}\text { Socio-Economic } \\
\text { consequences }\end{array}$} & SE1 & 4.16 & 1.14 & \multirow{9}{*}{25.20} & \multirow{9}{*}{ - } & \multirow{9}{*}{$\begin{array}{l}10 \\
\infty \\
0 \\
0 \\
0\end{array}$} & \multirow{9}{*}{ 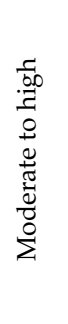 } & 7.32 & 2.10 & & & \multirow{9}{*}{$\begin{array}{l}\stackrel{0}{0} \\
0 \\
0\end{array}$} & \multirow{9}{*}{$\begin{array}{l}\frac{\pi}{00} \\
.0 \\
0 \\
0 \\
0 \\
0 \\
\frac{\pi}{0} \\
0 \\
0 \\
0\end{array}$} \\
\hline & SE2 & 3.85 & 1.25 & & & & & 7.20 & 2.03 & & & & \\
\hline & SE3 & 3.50 & 1.46 & & & & & 6.52 & 2.46 & & & & \\
\hline & SE4 & 3.18 & 1.36 & & & & & 7.23 & 2.04 & & & & \\
\hline & SE5 & 3.33 & 1.29 & & & & & 7.55 & 1.68 & 59.05 & 11.99 & & \\
\hline & SE6 & 3.54 & 1.06 & & & & & 6.89 & 1.58 & & & & \\
\hline & SE7 & 3.63 & 1.43 & & & & & 7.33 & 2.30 & & & & \\
\hline & SE8 ${ }^{c}$ & - & - & & & & & 3.92 & 2.37 & & & & \\
\hline & SE9 ${ }^{\mathrm{C}}$ & - & - & & & & & 5.09 & 2.24 & & & & \\
\hline \multirow{5}{*}{$\begin{array}{l}\text { Organizational } \\
\text { consequences }\end{array}$} & O1 & 3.63 & 1.01 & \multirow{5}{*}{10.16} & \multirow{5}{*}{ - } & \multirow{5}{*}{$\begin{array}{l}\stackrel{n}{2} \\
\stackrel{0}{0} \\
0\end{array}$} & \multirow{5}{*}{$\begin{array}{l}\frac{0}{0} \\
\frac{\pi}{0} \\
\frac{0}{0} \\
0 \\
\Sigma\end{array}$} & 6.33 & 1.78 & & & \multirow{5}{*}{$\begin{array}{l}0 \\
10 \\
0 \\
+ \\
0\end{array}$} & \multirow{5}{*}{ 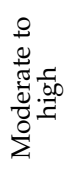 } \\
\hline & $\mathrm{O} 2$ & 3.70 & 1.08 & & & & & 7.00 & 2.01 & & & & \\
\hline & $\mathrm{O} 3$ & 2.84 & 1.35 & & & & & 6.92 & 1.93 & 30.24 & 5.60 & & \\
\hline & $\mathrm{O} 4^{\mathrm{c}}$ & - & - & & & & & 6.94 & 1.85 & & & & \\
\hline & $\mathrm{O} 5^{\mathrm{c}}$ & - & - & & & & & 3.05 & 1.95 & & & & \\
\hline \multirow{6}{*}{$\begin{array}{l}\text { Agro-Environmental } \\
\text { consequences }\end{array}$} & AE1 & 3.93 & 1.36 & \multirow{6}{*}{22.43} & \multirow{6}{*}{2.53} & \multirow{6}{*}{$\begin{array}{l}0 \\
\infty \\
\stackrel{0}{0} \\
0\end{array}$} & \multirow{6}{*}{$\begin{array}{l}\frac{1}{00} \\
.0 \\
0 \\
0 \\
0 \\
0 \\
\frac{\pi}{0} \\
\frac{0}{0} \\
0 \\
\Sigma\end{array}$} & 6.12 & 2.26 & & & \multirow{6}{*}{$\begin{array}{l}0 \\
0 \\
0 \\
0\end{array}$} & \multirow{6}{*}{ 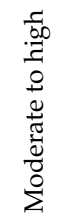 } \\
\hline & AE2 & 4.03 & 1.18 & & & & & 6.55 & 2.21 & & & & \\
\hline & AE3 & 3.49 & 1.37 & & & & & 7.05 & 2.37 & 4170 & 1038 & & \\
\hline & $\mathrm{AE} 4$ & 3.64 & 1.27 & & & & & 7.26 & 2.19 & 41.19 & 10.30 & & \\
\hline & AE5 & 3.51 & 1.31 & & & & & 7.35 & 2.10 & & & & \\
\hline & AE6 & 3.83 & 1.14 & & & & & 7.47 & 2.15 & & & & \\
\hline \multirow{4}{*}{$\begin{array}{l}\text { Technological } \\
\text { consequences }\end{array}$} & $\mathrm{T} 1$ & 2.66 & 1.60 & \multirow{4}{*}{7.69} & \multirow{4}{*}{4.37} & \multirow{4}{*}{$\begin{array}{l}\stackrel{10}{2} \\
0 \\
0 \\
0\end{array}$} & \multirow{4}{*}{ 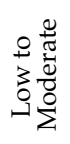 } & 6.73 & 2.21 & & & & 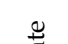 \\
\hline & $\mathrm{T} 2$ & 2.46 & 1.61 & & & & & 5.41 & 2.44 & & & 아 & 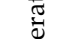 \\
\hline & T3 & 2.57 & 1.6 & & & & & 5.23 & 2.39 & 22.83 & 5.52 & $\stackrel{0}{0}$ & ర్ర \\
\hline & $\mathrm{T} 4^{\mathrm{c}}$ & - & - & & & & & 5.47 & 2.40 & & & & $\Sigma$ \\
\hline
\end{tabular}

a: Responses weighted 0 to 5: from none (0), very low (1), low (2), moderate (3), high (4) and very high (5).

$\mathrm{b}$ : Responses weighted 1 to 10: from very low (1) to very high (10). ${ }^{c}$ : In this case, the farmers were not asked. SE: Socio-Economic consequences, O: Organizational consequences, AE: Agro-Environmental consequences,

T: Technological consequences. 


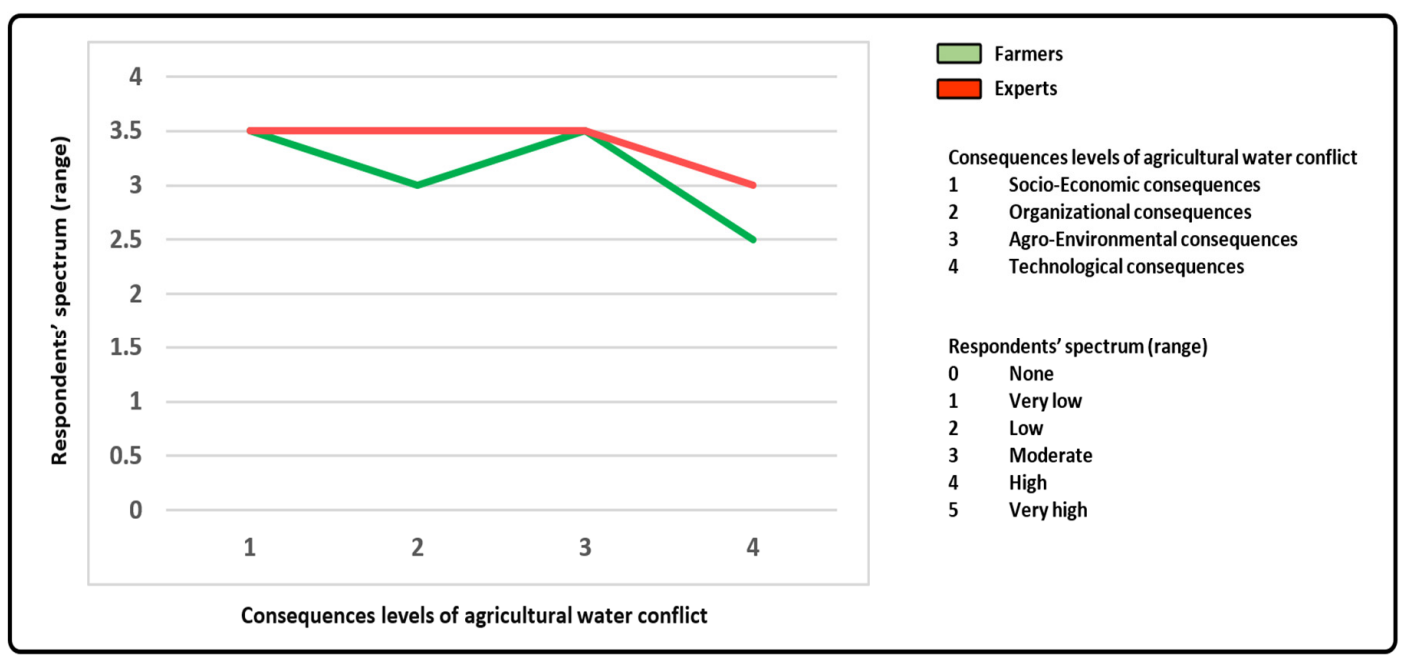

Figure 5. Consequences levels of agricultural water conflict according to respondents' opinion. Source: Surveys' result.

\subsubsection{Consequences: Interviews' Results}

To fully understand the consequences of agricultural water conflicts, an open interview was conducted among 10 farmers who were selected in the qualitative phase of the research. Repeated concepts in their statements about the causes of water conflicts were recorded. These concepts, separated and enumerated, are presented in Table 6.

The concepts were classified according to surveys into four categories (socio-economic, organizational, agro-environmental, and technological consequences). Findings showed that socio-economic and agro-environmental consequences had the highest frequency. This finding confirms the survey findings (Table 5). Furthermore, findings about organizational and technological consequences are the same as the findings in the quantitative phase.

Table 6. Analysis of water conflict consequences by enumeration technique.

\begin{tabular}{|c|c|c|c|c|c|}
\hline \multirow{2}{*}{ Consequences } & \multirow{2}{*}{ Concepts } & \multicolumn{4}{|c|}{ Repetition } \\
\hline & & Upstream & Downstream & & Total \\
\hline \multirow{6}{*}{$\begin{array}{l}\text { Socio-economic } \\
\text { consequences }\end{array}$} & $\begin{array}{l}\text { Decrease of production and income in } \\
\text { agriculture }\end{array}$ & 4 & 3 & 8 & \multirow{6}{*}{30} \\
\hline & Increasing production costs & 4 & 3 & 8 & \\
\hline & Increase in the rate of migration to cities & 2 & 3 & 5 & \\
\hline & Growing lack of security and theft & 2 & 3 & 5 & \\
\hline & Increase in the rate of unemployment & 1 & 2 & 3 & \\
\hline & Distrust and despair & 0 & 2 & 1 & \\
\hline \multirow{5}{*}{$\begin{array}{l}\text { Agro-environmental } \\
\text { consequences }\end{array}$} & Increasing pressure on agricultural lands & 4 & 2 & 6 & \multirow{5}{*}{22} \\
\hline & Environmental degradation & 3 & 2 & 5 & \\
\hline & Lack of crop rotation & 3 & 1 & 4 & \\
\hline & Using drainage water instead of clean water & 0 & 4 & 4 & \\
\hline & $\begin{array}{l}\text { Digging illegal wells and more pressure on } \\
\text { groundwater resources }\end{array}$ & 3 & 0 & 3 & \\
\hline \multirow{3}{*}{$\begin{array}{l}\text { Organizational } \\
\text { consequences }\end{array}$} & $\begin{array}{l}\text { Decrease in collaboration to make an } \\
\text { association for water management }\end{array}$ & 2 & 2 & 4 & \multirow{3}{*}{10} \\
\hline & $\begin{array}{l}\text { Decreasing participation in water } \\
\text { management }\end{array}$ & 2 & 2 & 4 & \\
\hline & $\begin{array}{l}\text { Increasing mentality to work individually } \\
\text { and avoid teamwork }\end{array}$ & 2 & 0 & 2 & \\
\hline \multirow{2}{*}{$\begin{array}{l}\text { Technological } \\
\text { consequences }\end{array}$} & Damage to irrigation canals & 4 & 0 & 4 & \multirow{2}{*}{6} \\
\hline & Farmers' resistance against water projects & 1 & 1 & 2 & \\
\hline
\end{tabular}


Figure 6 can be presented as a summary of the results. As can be seen, the causes of agricultural water conflict can be grouped into two categories: Controllable and uncontrollable. The uncontrollable factors are those changes that cannot be controlled by human factor (e.g., farmers) in the short-term. These factors are mostly related to environmental issues such as climate change, natural disasters, etc. However, the controllable factors refer to issues that are at the disposal of human beings and are related to the type of human interventions in natural resources. There are also schematically different types of consequences of water conflict in this figure. This division is based on the extent of human intervention and influence in controlling the causes and consequences of water conflicts.

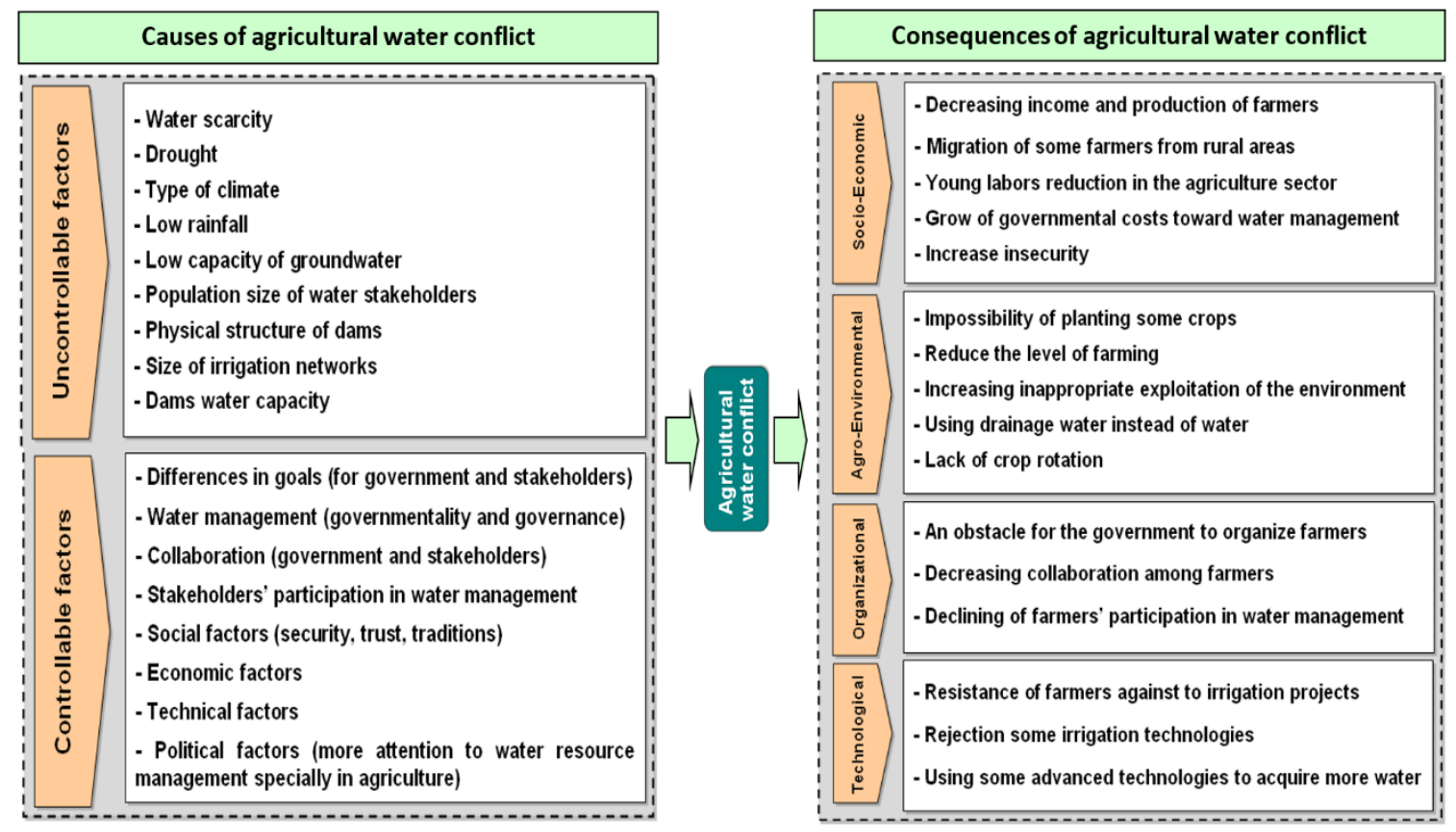

Figure 6. Causes and consequences of agricultural water conflict: A determining model. Source: Surveys' result.

\section{Discussion}

According to our findings, there was no general difference between opinions of farmers and regional water experts toward agricultural water conflict and their opinions. In fact, they were unanimous about water conflict in agricultural sector and had a shared understanding in this area. The findings of this study also confirmed that there was a moderate to high level water conflict in Doroodzan dam irrigation network. Where most of the water battles are waged in court today, conflict is usually avoided as much as possible. Conflict can be avoided with cooperation and use of modern technologies. However, the conflict is a more serious challenge when it comes to more vulnerable communities. Areas with fewer resources and no access or legal processing facilities are more likely to find themselves in a violent conflict over water. Injustice would make desperate farmers more likely to take water by force. It will be up to decision makers to realize that it might be better not to cut water completely, but to negotiate and find an agreement with everyone. Daoudy (2009) [46] focused on the prospect of negotiating theories for regions for which power, military, and economic resources are mostly used as a solution to overcome conflict. His study showed how Syria was effectively using the issue-linking tactics with Turkey, where support for the Kurdish rebels was a main factor in controlling the water allocation based on the agreement of 1987.

The results of current study showed that agricultural water conflict is growing strongly. The main reasons for this increasing conflict were "drought", "water scarcity", "lake of local management of water resources by farmers", and "type of water management quality by the government". Therefore, one can say at the present time, the main challenges of agricultural water conflict in Doroodzan dam irrigation 
network are related to climate changes and water management. The practical recommendation for regional water experts is to focus on these factors, especially in terms of improving water resource management in unfavorable climate conditions. Appropriate strategies to cope with drought and water scarcity are providing applied training for proper and optimal use of water, drought-resistant crops, and the use of modern technologies consuming water in sustainable manner. Focusing on water management, the best strategy in this regard is moving from government centrality to governance. This finding is in line with the study of Al Obaidy et al. (2013) [47] as they also investigated the socio-economic challenges to water sustainability in Iraq. Their work indicated the need for a comprehensive national plan. Their results have shown that upstream country development projects have led to significant degradation of water quantity and quality. The country faces a major threat to desertification. They also emphasized the displacement of the population, which caused violent conflicts over water.

In fact, water resource management in Iran should move from government centrality to governance and the government should make efforts to attract farmers' participation in this process. The farmers' participation in water management and the government's cooperation and support is an appropriate solution. In the current research, the experts believed that the most important reference for water resource management is local people and farmers. On this basis, the role of the government should be only supportive and regulatory. The main responsibility of water experts is gradually assigning farmers to manage their water resources by training them, increasing their motivation and participation in local communities, particularly in constituting and the establishment of effective water use associations. Focusing on the Iranian context, Bijani and Hayati (2016) [48] concluded that the most important water conflict is between water stakeholders and the government, and that the best solution to this conflict is to move from government centrality to governance. It means there should be some programs toward stakeholders' participation in water management.

In most parts of Iran, on one hand, the water level is low, and due to water scarcity, distribution of water among stakeholders is very complicated and difficult. On the other hand, some of the main causes of water conflict are out of human control. According to the findings, the causes of agricultural water conflict can be grouped into two categories-controllable and uncontrollable. The results of the qualitative and quantitative phases of the study showed that the main causes of water conflict are out of human control. These factors are related to natural events such as drought and water scarcity. Therefore, they are called uncontrollable factors. The most significant controllable factors are related to water resource management in the current situation. In addition, in this study, the consequences of agricultural water conflicts are classified into four groups: 'socio-economic', 'agro-environmental', 'organizational', and 'technological'. Among them, socio-economic and agro-environmental backgrounds are more important. The reason is that water scarcity, societal inequalities in access to and decision-making on water, can be a threat to the quality of life of stakeholders and an obstacle to sustainable livelihood and environmental development. In this context, policymakers in water resources management should focus on changing water stakeholders' environmental attitudes and behaviors, understanding their real needs, and using appropriate technologies. In the case of ecological views, if the dominant view of farmers is biospheric and altruistic, there will be less conflict in their use of water, and the more their views are selfish (egoistic), the greater their behavioral contradictions. This has been confirmed in the other studies (for example: [2]). Therefore, these policies should move toward changing environmental views.

What has been overlooked in recent years by government management is the lack of involvement of farmers, the emphasis on advanced technological (not commensurate) issues, and the imbalance between agriculture and the environment. These findings are quite consistent with the findings of other researchers on the reasons for water conflict and the emphasis on stakeholder participation in water resources management (see $[2,3,14,18,19,22])$. However, the findings related to the consequences of water conflict, especially in Iran, were less considered and no similar study was found. Therefore, these findings can be verified and adapted in a variety of ways. 


\section{Conclusions}

The findings of this study can be useful in conceptualizing and perceiving water resource management based on the mix-method approach perspective. As mentioned earlier, Iran's villagers are dealing with significant water conflicts. Although the drought phenomenon during the last 10 years have increased the conflict in most regions of Iran, and thus less water availability for stakeholders, it must be noted that this is not a new problem in Iran's civilization. What can create a balance between supply and demand of water and reduce the impact of uncontrollable factors is proper water resource management. In Iran, water management is being introduced by the government, and farmers, particularly those in the agricultural sector, lack the encouragement needed for optimal water management. Clearly, such a situation drives the individuals to act based on their personal preferences and maximum use of water. The same findings have also been discussed in similar studies [2,49]. To achieve proper management, there is an obvious need to find coordination between the purposes of water managers and farmers and induce participation, motivation, and cooperation among them. Current water management in Iran is not responsible for this interaction and balance. Rotation of governmentality to governance towards water management is a suitable approach for resolving water conflicts and reduces inappropriate social, economic, and environmental consequences. As mentioned earlier, in Iran, the government is responsible for water resources. In this way, water beneficiaries find themselves in the role of "owners" of water resources. Therefore, there will be more guarantees to protect of these resources. Centralized management, i.e., the government, has no ability to organize and direct stakeholders' participation to use water resources efficiently. Reduction in water conflict and increase in cooperation depend on water users' participation. As farmers think of themselves only as water users, they focus on accessing more water to produce more crops. In this regard, the mission of agricultural extension should be to provide the necessary knowledge and change attitudes toward such transmission.

In fact, proper management and cooperation of all farmers can reduce the effects of uncontrollable causes of water conflicts. It can be effective to organize, educate, and promote farmers to cultivate crops that are resistant to water scarcity stress during drought and to use technologies for better management of water in agriculture. This requires organization and coordination among related institutions and farmers. There is also a need for proper training for the proper use of water and the spread of a culture of saving water resources. The role of education as a tool to implement these changes is undeniable. In this regard, agricultural extension and education through practical training towards the use of water and related issues can play an important role in attracting farmers' participation and in transforming conflicts to collaboration.

What was proposed in this study was simply to define the causes and implications of the water conflict. The next critical step is to find a way to stop conflicts over water and their negative consequences. In this regard, this study suggests that the future researches focus on the following subjects:

- Evaluating the impact of water conflicts among rural people and farmers;

- Assessing the relationship between human ecological and water conflicts in agriculture;

- Performing meta-analysis on water conflict in terms of scientific, social, economic, and environmental perspective; and

- Analyzing the relationship between water conflict and water management in terms of moral and ethical perspective.

Author Contributions: Conceptualization: M.B. and D.H.; methodological setup: M.B.; data analysis: D.H., H.A.; writing of the original draft: M.B.; review, editing and helping with addressing comments M.B. and H.A.; editing and helping with addressing comments: V.T. and F.W. All authors have read and agreed to the published version of the manuscript.

Funding: This research has not received any external funding. 
Acknowledgments: The authors express appreciation of numerous rural people, farmers and experts for sharing their resources and ideas during the study. Our express appreciation also to G.H. Karami, B. Abadi, S. Zare, $\mathrm{H}$. Gheisari, J. Jowkar and A. Malekian who had a great assistance in conducting research and gathering information.

Conflicts of Interest: The authors have no conflict of interests.

\section{References}

1. Burch, C.; Busch, M.; Higgins, E.; Bittner, S.; Perera, N.; Neal, K.; Burkett, L.; Castro, A.J.; Anderson, C. Revisiting a Water Conflict in Southeastern Oklahoma 6 Years Later: A New Valuation of the Willingness to Pay for Ecosystem Services. Sustainability 2020, 12, 819. [CrossRef]

2. Bijani, M.; Hayati, D. Farmers' perceptions toward agricultural water conflict: The case of Doroodzan dam irrigation network, Iran. JAST 2015, 17, 561-575.

3. Veisi, K.; Bijani, M.; Abbasi, E. A Human Ecological Analysis of Water Conflict in Rural Areas: Evidence from Iran. Glob. Ecol. Conserv. 2020, 23, e01050. [CrossRef]

4. Coser, L.; Dahrendorf, R.; Collins, R. Theory Cumulation and Schools of Thought. Chapter 7: Conflict and Critical Theories. 2006. Available online: www.sagepub.com/upm-data/13636_Chapter7.pdf (accessed on 22 November 2006).

5. Tian, G.; Han, X.; Zhang, C.; Li, J.; Liu, J. Virtual Water Flows Embodied in International and Interprovincial Trade of Yellow River Basin: A Multiregional Input-Output Analysis. Sustainability 2020, 12, 1251. [CrossRef]

6. Toset, H.P.W.; Gleditsch, N.P.; Hegre, H. Shared rivers and interstate conflict. Polit. Geogr. 2000, 19, 971-996. [CrossRef]

7. Salehi, S.; Chizari, M.; Sadighi, H.; Bijani, M. Assessment of Agricultural Groundwater Users in Iran: A Cultural Environmental Bias. Hydrogeol. J. 2018, 26, 285-295. [CrossRef]

8. Kameri-Mbote, P. Water, Conflict, and Cooperation: Lessons from the Nile river Basin. In Navigating Peace; Woodrow Wilson International Center for Scholars: Washington, DC, USA, 2007; Volume 4.

9. Tulloch, J. Water Conflicts: Fight or Flight? Allianz. 2009. Available online: www.knowledge.allianz.com (accessed on 26 August 2009).

10. OECD (Organization for Economic Co-Operation and Development). Mainstreaming Conflict Prevention: Water and Violent Conflict; OECD: Paris, France, 2005.

11. Huffaker, R.; Hamilton, J. Conflicts. In Irrigation of Agricultural Crops, 2nd ed.; Lascano, R.J., Sojka, R.E., Eds.; Agronomy Monograph no. 30; ASA-CSSA-SSSA Publishing: Madison, WI, USA, 2007; 664p.

12. Khoshbakht, K. Country Report: Islamic Republic of Iran. In Proceedings of the Workshop on Climate Change and Its Impact on Agriculture, Seoul, Korea, 13-16 December 2011.

13. Ardekanian, R. Overview of Water Management in Iran. Policies and Strategic Options for Water Management in the Political Countries. In Proceedings of the Symposium organized by the Regional Centre on Urban Water Management (RCUWM-Tehran), Tehran, Iran, 15-16 December 2003; Available online: www.books.nap.edu (accessed on 15 January 2004).

14. Raeisi, A.A.; Bijani, M.; Chizari, M. The Mediating Role of Environmental Emotions in Transition from Knowledge to Sustainable Behavior toward Exploit Groundwater Resources in Iran's Agriculture. Int. Soil Water Conserv. Res. 2018, 6, 143-152. [CrossRef]

15. Beheshtinejad, S.H. The Importance of Correction of the Consumption Water Model in Agriculture. The News Web of Daylam. 2009. Available online: www.deilamnews.com (accessed on 10 November 2009).

16. Abbasian, A.R.; Chizari, M.; Bijani, M. Farmers' Views on the Factors Inhibiting the Implementation of Soil Conservation Practices (The Case of Koohdasht Township, Iran). JAST 2017, 19, 797-807.

17. Malekian, A.; Hayati, D.; Aarts, N. Conceptualizations of water security in the agricultural sector: Perceptions, practices, and paradigms. J. Hydrogeol. 2017, 544, 224-232. [CrossRef]

18. Shojaei-Miandoragh, M.; Bijani, M.; Abbasi, E. Farmers' Resilience Behavior in the Face of Water Scarcity in the Eastern Part of Lake Urmia, Iran: An Environmental Psychological Analysis. Water Environ. J. 2020. [CrossRef]

19. Bijani, M.; Hayati, D. Water conflict in agricultural system in Iran: A human ecological analysis. J. Ecol. Environ. Sci. 2011, 2, 27-40. [CrossRef] 
20. Green, B.E. Sharing Water: A Human Ecological Analysis of the Causes of Conflict and Cooperation between Nations over Freshwater Resources. Ph.D. Thesis, The Ohio State University, Columbus, OH, USA, 2002. Available online: www.etd.ohiolink.edu (accessed on 18 November 2002).

21. Mohammadinezhad, S.; Ahmadvand, M. Modeling the internal processes of farmers' water conflicts in arid and semi-arid regions: Extending the theory of planned behavior. J. Hydrogeol. 2020, 580, 124241. [CrossRef]

22. Hermann, W.P. Malthus and Darfur. Undergrad. Res. J. 2008, 1, 22-24.

23. Urdal, H. People vs. Malthus: Population Pressure, Environmental Degradation, and Armed Conflicts Revisited. J. Peace Res. 2005, 42, 417-434. [CrossRef]

24. Gorgoglione, A.; Crisci, M.; Kayser, R.H.; Chreties, C.; Collischonn, W. A New Scenario-Based Framework for Conflict Resolution in Water Allocation in Transboundary Watersheds. Water 2019, 11, 1174. [CrossRef]

25. Tabara, J.D.; Pahal-Wostl, C. Sustainability learning in natural resource use and management. Ecol. Soc. 2007, 12, 3. [CrossRef]

26. Sadeghi, A.; Bijani, M.; Farhadian, H. The Mediating Role of Farmers' Time Perspective in Water Resources Exploitation Behaviour in the Eastern Area of Lake Urmia, Iran: An Environmental-Psychological Analysis. Water Environ. J. 2020. [CrossRef]

27. Marciano, A. Economists on Darwin's theory of social evolution and human behavior. Eur. J. Hist. Econ. Thought 2007, 14, 681-700. [CrossRef]

28. Shiri, S.; Bijani, M.; Chaharsoughi Amin, H.; Noori, H.; Soleymanifard, A. Effectiveness Evaluation of the Axial Plan of Wheat from Expert Supervisors' View in Ilam Province. World Appl. Sci. J. 2011, 14, 1724-1729.

29. Tahir, B.A. Practical Guide, Tips for Conflict Reporting; INTERMEDIA: Islamabad, Pakistan, 2009; ISBN 9789699209024. Available online: www.mywwesearch.swagbucks.com (accessed on 10 October 2009).

30. Said, S. Kiru Valley Complexity: A Case Study Over Consequences of and Causes to Conflicts Over Irrigation Water in Tanzania. Master's Thesis, Sodertorns University College, Huddinge Municipality, Sweden, 2008. Available online: www.sh.diva-portal.org/smash/record.jsf?pid=diva2:37485 (accessed on 5 January 2008).

31. Swedish Water House. Water and Local Conflict: A Brief Review of the Academic Literature and Other Sources; Swedish Water House: Stockholm, Germany, 2004; Available online: https://www.swedishwaterhouse.se/ swh/resources/20050425162906Water_and_Local_Conflict.pdf (accessed on 12 October 2004).

32. INWEB. From Potential Conflict to Cooperation Potential (PCCP) in SE Europe, 17th-21st October 2006, Thessaloniki, Greece. Available online: http://www.unesco.org/water/wwap/pccp (accessed on 17 August 2020).

33. Haftendorn, H. Water and International Conflict. Third World Q. 2000, 21, 51-68. [CrossRef]

34. Marcantonio, R.A.; Attari, S.Z.; Evans, T.P. Farmer Perceptions of Conflict Related to Water in Zambia. Sustainability 2018, 10, 313. [CrossRef]

35. Zou, Y.; Duan, X.; Xue, Z.; E, M.; Sun, M.; Lu, X.; Jiang, M.; Yu, X. Water use conflict between wetland and agriculture. J. Environ. Manag. 2018, 224, 140-146. [CrossRef] [PubMed]

36. Homer-Dixon, T. Environmental Scarcities and Violent Conflict. Evidence from Cases. Int. Sec. 1994, 19, 5-40. [CrossRef]

37. Gizelis, T.I.; Wooden, A.E. Water resources, institutions, \& intrastate conflict. Polit. Geogr. 2010, $29,444-453$.

38. Bohmelt, T.; Bernauer, T.; Buhaug, H.; Gleditsch, N.P.; Tribaldos, T.; Wischnath, G. Demand, supply, and restraint: Determinants of domestic water conflict and cooperation. Glob. Environ. Chang. 2014, 29, 337-348. [CrossRef]

39. Hsiang, S.M.; Meng, K.C. Reconciling Disagreement Over Climate-Conflict Results in Africa. Proc. Natl. Acad. Sci. USA 2014, 111, 2100-2103. [CrossRef]

40. O'Loughlin, J.; Linke, A.M.; Witmer, F.D. Modeling and data choices sway conclusions about climate-conflict links. Proc. Natl. Acad. Sci. USA 2014, 111, 2054-2055. [CrossRef]

41. Hayati, D.; Karami, E. Typology of causes of poverty: The perception of Iranian farmers. J. Econ. Psychol. 2005, 26, 884-901. [CrossRef]

42. Azizi Khalkheili, T.; Zamani, G. Farmer participation in irrigation management: The case of Doroodzan Dam Irrigation Network, Iran. J. Agric. Water Manag. 2009, 96, 859-865. [CrossRef]

43. Zare, S.; Hayati, D. Consequences Appraisal of Irrigation Networks Development Based on Farmers' Viewpoint in Downstream of Doroodzan Dam, Fars. J. Water Soil 2017, 24, 87-106.

44. Yazar, A.; Gökçel, F.; Sezen, M.S. Corn yield response to partial rootzone drying and deficit irrigation strategies applied with drip system. Plant Soil Environ. 2009, 55, 494-503. [CrossRef] 
45. Hohenwallner, D.; Marie Saulnier, G.; Cataings, W.; Astengo, A.; Brencic, M.; Bruno, M.C.; Carolli, M.; Chenut, J.; De Bona, A.; Doering, M.; et al. Water Management in a Changing Environment: Strategies against Water Scarcity in the Alps Project Outcomes and Recommendations. Water Management in a Changing Environment. Alp-Water-Scarce Oct; Université de Savoie: Chambéry, France, 2011.

46. Daoudy, M. Asymmetric power: Negotiating water in the Euphrates and Tigris. Int. Negot. 2009, 14, 361-391. [CrossRef]

47. Al Obaidy, A.H.M.J.; Al-Khateeb, M. The challenges of water sustainability in Iraq. Eng. Technol. J. Part A Eng. 2013, 31, 828-840.

48. Bijani, M.; Hayati, D. Agricultural Water Conflict Management in Iran: Governance or Governmentality. In Proceedings of the 3rd International Conference on Research in Science and Technology, Berlin, Germany, 9 July 2016. [CrossRef]

49. Boazar, M.; Yazdanpanah, M.; Abdeshahi, A. Response to water crisis: How do Iranian farmers think about and intent in relation to switching from rice to less water-dependent crops? J. Hydrol. 2019, 570, 523-530. [CrossRef]

(C) 2020 by the authors. Licensee MDPI, Basel, Switzerland. This article is an open access article distributed under the terms and conditions of the Creative Commons Attribution (CC BY) license (http://creativecommons.org/licenses/by/4.0/). 